\title{
The Implementation of Curriculum at Kuttab Al-Fatih Surabaya
}

\author{
Muhammad Yudo \\ Agression of Akbaril, Master of Islamic Education Management, \\ Universitas Muhammadiyah Sidoarjo, Indonesia \\ abinyafarros@gmail.com,_@umsida.ac.id
}

Rahmad Salahuddin

Master of Islamic Education Management, Universitas Muhammadiyah Sidoarjo, Indonesia

shd.rahmad2013@gmail.com,_@umsida.ac.id

\begin{abstract}
This research describes the concept of the kuttab curriculum during the ancient time and its implementation at the lembaga pendidikan kuttab al-fatih surabaya as part of the national education system. This research is qualified as a special study approach. The data is collected using interview, observation and documents. Whereas in analyzing data it uses the concept of analysis of miles and huberman, which is data reduction, data presentation and making conclusion. This research concludes that: 1 . Formerly the concept of the kuttab curriculum during the ancient time was made only to wish for allah's blessing but later developed to have a social and even material aim. Also the content of its curriculum is very simple and uses a separate curriculum pattern. 2 . The concept of the kuttab curriculum which is applied at the lembaga pendidikan kuttab al-fatih surabaya contains the aim and contents of the curriculum, teaching method and the system of evaluation as well. Kuttab al-fatih educational institution surabaya also uses an informal education (pusat kegiatan belajar masyarakat/pkbm) in applying its educational program by creating an equivalence program in order to achieve the primary education diploma known as the package a diploma as part of the national education which is available in indonesia
\end{abstract}

Keywords: Curriculum implementation, kuttab al-fatih.

\section{INTRODUCTION}

In the Law on the National Education System, it is explained that the aim of education is to educate the lives of the nation and to develop Indonesian people as a whole, namely people who have faith and are devoted to God Almighty and have noble character, possess knowledge and skills, physical and spiritual health, personality a steady and independent and a sense of community and national responsibility [1].

From the above, we can understand that the education team in Indonesia is contained in 3 things:

1. Strengthen religious beliefs, high mentality, morals, and character,

2. Increase intelligence skills

3. and fostering / developing strong and healthy physical [2].

Based on this we see that the first and a priority in national education is to instill the value of faith and devotion to God Almighty, therefore the national education system must always be associated with religious nuances and breathe in divine values in accordance with the mandate stated in in the Basic Law to achieve the goal of national education that is to give birth to a generation that is not only intelligent and skilled and has personality, but also becomes a complete human being based on faith and devotion to God Almighty.

To realize these educational goals, we know that there are three educational pathways in Indonesia, namely formal education, non-formal education and information education [3]. During this time formal education was the place most in demand by the community in sending their children to increase knowledge which was mostly carried out by the government. This is not strange, because among the advantages of formal education, among others, namely more regular, systematic, tiered, and divided into a certain time from since kindergarten to university [4].

However, the reality that is in our midst, shows that the existing formal education cannot fully accommodate the needs of parents in sending their children to receive sufficient religious education. So that the opportunity finally made various parties, especially from the private sector, make formal Islamic schools or 
madrasas that offer learning programs not only oriented to the general material but also include religious money material needed by their students.

According to Hartono [5] the main cause of people choosing Islamic nuance school as a place to send their children to school is because this school applies education to the worldly future (general science) and the afterlife (religious knowledge) well. Meanwhile, according to Asrohah, this phenomenon actually shows a modern phenomenon in the system of Islamic education, meets the needs of modernization, classical systems, the use of benches, even incorporating general knowledge as part of its curriculum, not secular and spreading ideas of religious renewal.

Nevertheless, according to Abdullah Malik Fadjar, the Islamic school or madrasah still has weaknesses, because the level of religious studies is only $30 \%$ of all subjects and the other $70 \%$ is filled with general lessons according to public school standards [6]. For this reason, if it is seen, there is still no balance between general lessons and religious lessons in it.

Another weakness is the lack of focus on how to implement the theory of religion in the life values of students. Religious education which is held more alone, lacks interaction with other educational activities, is less effective in understanding complex values [7]. Behind this there have been many non-formal education institutions that offer alternative curricula that are oriented towards understanding and practicing religious values. Nurani stated that starting with superior non-formal education, Islam is able to prevent the destruction of morality due to the factors of globalization through the enhancement of cultural / traditional values and re-emergence of rites and religious values while paying attention to modernization, offering a model of child learning that attracts parents, organized in a modern way, such as the fullday school system, so that non-formal education institutions are rapidly growing in demand by the community [8].

One of the currently developing non-formal educational institutions is the Institution which calls itself the Kuttab al-Fatih Educational Institution. This institution is an institution whose curriculum is a reflection of the Kuttab institution in classical times.

According to Ahmad Syalabi explained that kuttab in classical times was the place to provide the lowest level of teaching, the majority of historical researchers agreed on this. As for George Makdisi distinguishes two forms of basic education (Maktab / Kuttab). According to him maktab is different from kuttab [9].

The Kuttab Al-Fatih Institute is an institution devoted to children aged 5-12 years whose criculum emphasizes the curriculum of faith and the curriculum of the Koran. Education in this Kuttab refers to the education of kuttab in classical times. the goal to be achieved is to achieve the glory of Muslims who are rooted in the Qur'an and sunnah. so this Kuttab wants to reorient education in classical times that have succeeded and brought about the glory of Islam, namely the Prophet's time, the Companions, the Umayyads and the Abbasids [10].

In this study there are several studies related to the discussion that researchers do, including:

First, the research conducted by Ridwan Kurniawan (2016) with the title of the study: "The Implementation of Elementary School Alternative Education in PKBM Sanggar Anak Alam (Salam) Bantul", the research results obtained in the form of description of the management implementation in the school which includes planning, implementation and evaluation is accompanied by an explanation of the educational results or achievements and the factors that influence it.

Secondly, the research conducted by Wahyudi and Dedih Surana (2017) with the research title "Descriptive Analysis of Islamic Education Curriculum Model Kuttab al-Fatih Bandung.", The results obtained from the study explain the curriculum model applied, the methods and methods of evaluation used.

The research has a different position, namely to describe the concept of the Kuttab curriculum itself in the Islamic education system and its implementation in the Kuttab al-Fatih Education Institute Surabaya as part of our national education system at this time.

\section{MAIN PART}

This study menggunaka n $\mathrm{S}$ qualitative approach with descriptive analysis. The qualitative research paradigm is thinking inductively. Each problem is seen as a micro-case, and then drawn in a more general context [11].

Quoting from Groman and Clayton that the ultimate goal of qualitative writing is to understand what is learned from the perspective of the incident itself from the point of view of the event itself [12].

This study is in the form of a case study, therefore this study uses a qualitative and descriptive-analysis approach related to how the curriculum is implemented in Kuttab al-Fatih Surabaya. 


\section{Research Background}

This research was conducted at the Kuttab al-Fatih Surabaya non-formal education institution, having its address at Jl. Gubeng Kertajaya VD no. 47A Surabaya, and this research was conducted from 26 February 2018 to 13 July 2018.

\section{Data source}

Primary data is data that is directly related to research problems [13]. So that it becomes data that directly provides data to data collectors [14]. Primary data in this study are data taken directly by researchers in the form of observations and interviews.

The secondary data is data that is not directly related to the research problem and is obtained from other sources [15]. Secondary data of this study were taken from the results of documentation either text or in the form of artifacts.

\section{Data collection technique \\ 1. Observation}

Observations can be interpreted as observations of objects, both directly and indirectly [16]. And this observation is done by researchers when learning activities are carried out in classes, so that the data obtained is truly in accordance with the actual situation.

\section{Interview}

An interview is a dialogue between researchers and certain people to get the information they want [17]. And the informant in taking data with this interview technique is the principal, curriculum coordinator and teaching staff.

\section{Documentation}

Simply reviewing documentation is a way of collecting information obtained from documents [18]. With this documentation review, researchers will explore data about institutions, education actors and those related to the curriculum at Kuttab al-Fatih Surabaya.

\section{Data analysis technique}

The data analysis technique used is the Miles and Hubermen data analysis model which consists of 3 steps: 1). data reduction (data reduction); 2). data presentation (data display); 3). Verification [19].

The analysis step analysis model based on this research, researchers will first eduksi mer data collected either comes from observation, interviews and documentation concerning curriculum implementation Kuttab al-Fatih Surabaya. The data reduction that researchers did was to sort and select data, classify and make a summary of the data obtained which had a relationship with the formulation of the problem. Second, then, the researcher will present or present data (data display) by presenting core data or principal after all data that has been collected is reduced. Third, or the last is verification. At this stage of this analysis, we propose or conclude the findings of the data obtained, which had previously been confirmed melakuk a $\mathrm{n}$ crosscheck the field to strengthen and acquire additional data as the data validity support documents.

\section{Data validity}

To test the validity of the data obtained, the researchers used triangulation techniques. As expressed by Moleong, triangulation is a technique to check the validity of data that utilizes something born from outside the data for checking purposes or as a comparison of the data [20]. The triangulation approach that researchers use to obtain data validity is the data triangulation (source) and method triangulation approach. By triangulating the data, the researcher compares data sources, actually getting the data needed.

In addition, the researchers also compared the data generated from the various collection methods that researchers used, namely interviews, observation and documentation. From here also the researcher will crosscheck the data from the existing informants and then make comparisons of the various methods so that data can be truly tested.

\section{RESULTS}

1. Analysis of Kuttab Curriculum Implementation at the Kuttab al-Fatih Education Institute in Surabaya

\section{a. Curriculum objectives}

As for the curriculum, the Kuttab al Fatih Educational Institution is essentially to produce a brilliant generation at a young age. And the foundation of the curriculum is based on philosophical values, especially those related to aspects of religiosity. We can see this from the two core curriculum, namely the Faith curriculum and the Qur'an. 
So the purpose of the Kuttab curriculum that is to be achieved by the Kuttab al-Fatih Institute has the same direction as the Classic Kuttab, that is based on the values and demands of religion, but it has undergone a shift from the technical nature of the mastery of the material, to the goal of giving birth to graduates brilliant at an early age as the education he obtained Muhammad al-Fatih the conqueror of Constantinople.

\section{b. Curriculum content}

To support the achievement of curriculum objectives, it is necessary to have curriculum content in an Educational Institution. and if we look at the Kuttab in classical times, then we can understand that the curriculum at the classic Kuttab is still very simple, namely teaching the Koran, reading, literature, writing, memorizing. Mathematics and the basics of religion with a separate curriculum pattern approach.

It is different from the curriculum content in the Al-Fatih Kuttab Education Institute in Surabaya where the curriculum content has been grouped into 2 main curriculums namely the Faith curriculum that has used a thematic approach (integrated curriculum) in its teaching which also includes learning to count, write, and read and the curriculum al- The Qur'an which still uses a separate subject curriculum approach such as the classic Kuttab curriculum pattern, which consists of teaching tahsin / qiroah, kitabah, adab and tahfidzul Quran.

\section{c. Teaching Method}

The method used in classical Kuttab learning generally uses classical methods such as lectures, discussions, dictation, question and answer used in teaching reading, writing, arithmetic, literature and basic Islamic sciences and the drill or talqin and talaqqi methods in teaching al- The Quran is good in terms of reading and memorizing it. The Kuttab concept learning method applied in the Al Fatih Kuttab Education Institution in general does not have fundamental differences, and even tends to have no differences, including: Exemplary, Lecture method, discussion and question and answer, Talqin or Drill and also constructive Stories.

\section{d. Evaluation}

In terms of the evaluation system carried out in Kuttab Education in classical times, what researchers get is that the Prophet's measurement / evaluation system in general in the classical period of human behavior is not quantitative (with numbers), but qualitative.

The evaluation system applied in the Kuttab al Fatih Institute of Surabaya uses both formative and summative evaluation models.

2. Analysis of Kuttab Curriculum Implementation at the Kuttab al-Fatih Education Institute in Surabaya as part of the National Education System

In its development, Kuttab al Fatih Surabaya took non-formal pathways as its educational path. From the existing legislation, it can also be understood that non-formal education in Indonesia has received strong recognition in the laws of our country. Even the implementation was also regulated by the State [21].

\section{CONCLUTION}

From the research that the author did at Kuttab al-Fatih Surabaya it was concluded that:

1. The concept of the kuttab curriculum in the classical period initially had educational goals to expect blessings from the Almighty and then developed to community goals and even material. As well as the curriculum content is still very simple and uses a separate curriculum pattern.

2. The concept of the Kuttab curriculum that is applied in the Kuttab al-Fatih Education Institute in Surabaya covers the objectives of the curriculum, curriculum content, teaching methods and evaluation systems. And the Kuttab al-Fatih Educational Institution uses a non-formal education pathway (Community Learning Activity Center / PKBM) in implementing its education program by making the equality program obtain an equivalent $\mathrm{SD} / \mathrm{MI}$ certificate known as a package A diploma as part of the national education system Indonesia.

\section{REFERENCES}

1. "Undang-Undang Nomor 20 Tahun 2003 Tentang Sistem Pendidikan Nasional."

2. O. Hamalik, "Proses Belajar Mengajar." Jakarta, p. 82, 2013.

3. "Undang-Undang Nomor 20 Tahun 2003 Tentang Sistem Pendidikan Nasional Pasal 26."

4. D. H. Musthofa, "Mengembangkan Model Alternative Pendidikan Islam," in Ponpes Jagad Alimussirry, Surabaya, 2016, p. 34.

5. “ibid.".

6. A. M. Fajar, Reorientasi Islam. Jakarta: Fajar Ilmu Dunia, 1992.

7. "Ibid."

8. M. Djoko Hartono, Mengembangkan Model Alternative Pendidikan Islam, vol. 2016. Surabaya: Ponpes Jagad Alimussirry. 
9. "Ibid."

10. "http://kutabalfatih.com/Profil/.".

11. Musfiqon, Panduan Lengkap Metode Penelitian Pendidikan. Jakarta: Prestasi Pustaka, 2012.

12. S. Santana, Metode Penelitian Kualitatif, vol. 2007. Jakarta: Yayasan Obor Indonesia.

13. Musfiqon, Panduan Lengkap Metode Penelitian Pendidikan. .

14. Sugiyono, Metode Penelitian Kuantitatif, Kualitatif dan R\&D. Bandung: Alfabeta, 2010.

15. "ibid."

16. Emzir, Analisis Data: Metodologi Penelitian Kualitatif. jakarta: Rajawali Press, 2010.

17. S. Uraibij and M. Al, Manahij Al Bahs Al Ilmi. Amman: Dar Majd Lawi Linmasyr, 1999.

18. "Ibid."

19. Sugiyono, Metode Penelitian Kuantitatif Kualitatif Dan $R \&$ D. Bandung: Alfabeta.

20. L. J. Moleong, "Metodologi Penelitian Kualitatif." p. 330.

21. "Undang-Undang Nomor 20 Tahun 2003 Tentang Sistem Pendidikan Nasional." 